\title{
Editorial
}

\section{Linking the Traits of International Economic Law}

\author{
Thomas Cottier \\ World Trade Institute, University of Bern, Bern, Switzerland \\ Thomas.Cottier@wti.org
}

The effort of the G-2o and the Organisation for Economic Co-operation and Development (OECD) in 2021 to introduce a globally harmonized minimal corporate tax rate of $15 \%$ recalls that international economic law is the result of incremental and piecemeal processes responding to transnational regulatory needs. It does not stop short of what traditionally has been at the core of national sovereignty. The field started out with bilateral trade agreements, facilitating access to ports, partial reduction of tariffs and national treatment, including residence, at the heart of navigation and friendship treaties. The first multilateral effort was made in the field of intellectual property with the Paris and Berne Conventions in the late 19th century. In the 2oth century, it was followed in trade, after a failed attempt in the Versailles Treaty, after World War II by the General Agreement on Tariffs and Trade (GATT), subsequently the World Trade Organization (WTO), and the Bretton Woods Agreements in monetary affairs and reconstruction. Otherwise, most areas were left to unilateral or bilateral relations after the comprehensive approach of the Havana Charter of the United Nations for an International Trade Organization failed to materialize. In the 21st century, multilateralism has been weakened in a multipolar world, with the failure of the Doha Development Round of the WTO and the forum shifting to bilateral and plurilateral avenues. Recent years witnessed a renaissance of unilateralism in the wake of nationalism and the geopolitical contest between the United States and China.

Different traits of international economic law developed in isolation and fragmentation, at different speeds and different layers of governance. They 
formed a multitude of epistemic communities: trade lawyers, investment lawyers, competition lawyers, corporate lawyers, labour and human rights lawyers, tax lawyers, migration lawyers, energy lawyers, environmental lawyers, and so on. Responding to incremental regulatory needs, international economic law reflects a fragmentation which is typical for the historical and contemporary structure of public international law.

\section{Interdependence}

At a closer look, many of these traits of international economic law today overlap on substance. In a world economy shaped by global value chains and with more than $6 \circ \%$ of trade in components and unfinished products shipped for refinement or incorporation, rules on tariffs and non-tariff barriers do not merely serve open markets and market access, but also the protection of competition and of investment within markets. International trade regulation with its fundamental principles of non-discrimination secures equal conditions of competition for foreign and domestic firms and equal treatment by law and governments. They make up the main pillars of the overall system. The rules on services both serve international trade and investment. The four modes of supply not only entail cross-border trade, but also the supply of services by a subsidiary abroad, and thus foreign direct investment. The same is true for intellectual property. Principles and rules of protection not only serve the purpose of market access, but they equally provide minimal standards applicable to foreign direct investment. As a consequence, intellectual property rights increasingly are protected under bilateral investment agreements (BITs). Unfair competition rules under the Paris Convention and the Agreement on Trade-Related Aspects of Intellectual Property Rights (TRIPS Agreement) protect competitors, consumers and thus foreign investors alike. Monetary law and monetary stability amounts to an essential precondition of foreign trade and investment. Principles and rules of the trading system underpin domestic anti-trust rules, addressing the conduct of private companies.

And all these areas and traits share the same principles of public international law: the respect of self-determination and sovereignty, the prohibition of warfare and aggression, the commitments to the protection of human rights, the principle of a common heritage of mankind and perhaps tomorrow a principle of common concern of humankind obliging nations to enhance cooperation and compliance. They share the same principles of law recognized under the Statute of the International Court of Justice, in particular the principles of equity, good faith and proportionality and the emerging principles 
of sustainable development. They share the same principles of due process in settling international disputes in different fora of the different traits of the field. They share the same principles of economic countermeasures and sanctions, subject to special rules in specific areas, particularly in the field of trade.

There can be no doubt that all the different traits of international economic law overlap and interact in practice and the real world. They must be read together. They interact in legal practice, increasingly so in academia as well, while still suffering from epistemic communities even under the shared umbrella of public international law. The increase of transparency due to information technology has fostered interaction. Increasingly, rulings and judgments are mutually taken into account and form a common core of rules that transgress different forms and fora of regulation, which could be called the common law of international economic law.

The different traits of international economic law share common challenges and problems in relation to non-trade and non-investment concerns: the protection of the environment in the age of climate change, the respect and promotion of human rights and the rule of law within a decentralized system of governance, and the challenges of global labour and non-labour migration flows. They share the same problems of interfacing different traits within and outside of international economic law with other areas of international law within the framework of the Vienna Convention of the Law of Treaties.

The traits also share the same underlying questions of multi-layered governance. The issues are the same: To what extent do the respective fields call for transnational rules, minimal standards, harmonization, regional or global governance with a view to produce appropriate public goods and welfare effects? To what extent, on the other hand, should regulation left assigned to the Nation-State respect the principle of subsidiary?

In domestic law - while often facing tensions - all the different traits of international economic law and beyond fall under the same constitutional order. In European integration, this has been increasingly the case, moving towards transnational federalism. Setting out with free trade in goods, services, labour and free flow of capital, it today includes monetary affairs, investment, labour, migration, energy, the environment and many more areas under a common roof and is often shared between member States. In international law, new agreements - termed comprehensive economic cooperation agreements - also transgress the traditional fields of trade law and include labour, investment 
protection and promotion, competition, environment and energy, albeit often under different rules of dispute settlement.

Given all these overlaps, commonalities and challenges shared, the question arises whether the different traits of international economic law do not equally call for the unification under a common roof in the way it was aspired by the Havana Charter in the period of the 'clean slate' after World War II? In the present age of unilateralism, given increasing tensions between trading blocks and geopolitical aspirations, this seems to amount to a bridge too far and utterly unrealistic. Yet, in the long run, the costs of unilateralism may change perceptions and prepare the ground to go back to the drawing board. What this imports at this stage is an effort in research by academia to overcome the traditions of separate epistemic and specialized communities. The community of lawyers should actively connect the dots and increase interaction and debate in preparing the ground, expounding the interaction of different traits in greater detail and assessing the impact of overarching principles and rules on different areas and their interfaces. And based upon such findings, additional areas of law and policy may be incrementally introduced in the multilateral framework as new regulatory needs emerge. Primarily, the ground should be prepared to again take up efforts to integrate competition and investment law with trade regulation within the WTO. It may eventually be followed by other traits of international economic law, in particular labour standards, core human rights, and energy in the context of climate change.

\section{The Case of Competition and Investment Law}

The case for competition law mainly rests upon two arguments: Firstly, conditions of competition created by governments and those created by the conduct of the private sector and companies cannot be separated and need to be dealt with in tandem. Secondly, the advent of new communication technology, specifically the internet, as well as challenges at the global level have changed regulatory needs. As much as it calls for common rules on corporate taxation, it calls for common rules and procedures for harnessing companies with a global reach commensurate with an overall regulatory system that transgresses national jurisdiction and calls for closer transnational cooperation in policing such companies. The compartmentalization of different jurisdictions is neither an advantage for the public at large nor for the companies affected. 
The case for investment law mainly rests on the insight that the classical distinction of investment promotion and investment protection seems obsolete. The two cannot be clearly separated and should follow a coherent set of rules. Protection from arbitrary expropriation and the requirements of fair and equitable treatment should be aligned with the broader contemporary agenda of investment promotion and the effort to bring about non-discriminatory rights of establishment beyond traditional market access rights.

Both competition and investment law developed particular remedies, allowing the private sector to directly defend its rights against government intervention. In competition law, these rights form part of domestic law. Under investment protection, they are enshrined in private-State arbitration, which is available under many bilateral investment agreements. These remedies constitute the main reason for keeping competition and investment law as traits and regimes separate from multilateral trade regulation, which is limited to inter-State dispute regulation. Remedies are different. While investment protection is limited to financial compensation for private actors, and competition law to remove cartels, abusive conduct and prevent distorting mergers by means of imposing severe fines, international trade regulation obliges governments to bring inconsistent practices and regulations in line with obligations under international law. These remedies are subject to, and limited to, the withdrawal of trade concessions granted. Rights of private operators in competition and investment law thus transgress trade regulation and make up the main reasons for addressing them separately in economic agreements and for resisting their inclusion in the multilateral trading system under the umbrella of the WTO.

Such inclusion, as much as submitting competition and investment to regular dispute settlement, however, does not imply giving up private rights. Disciplines in WTO law would be addressed to Member States, including the obligation to make available appropriate remedies for private operators in domestic law. The core subject matter of dispute settlement in the WTO is whether Members properly comply with these obligations, inasmuch as such questions can already be raised under the TRIPS Agreement of the WTO, which, equally with GATS, recognizes and protects the rights of private actors. Moreover, the review of anti-dumping and countervailing duty determination concern specific impositions made upon private actors. Upon including investment and competition law, there is no need to formally extend WTO jurisprudence to private actors or to give up their respective remedies under the existing domestic and international law of BIT s. At the same time, it does 
not exclude the review of the procedural role of private parties in WTO dispute settlement.

Governments would be entitled to challenge domestic practices as to their compatibility and consistency with disciplines of WTO law on investment promotion and protection as well as on anti-trust. Firstly, this will be done by means of recourse to panels and strong involvement of the secretariat in preparing the case on the panel stage. The importance of creating competence within a single institution cannot be understated in the process of connecting the dots of international economic law. As much as the evolution of domestic law depends upon strong central courts of law, the evolution of international economic law and greater coherence depends upon legal expertise and know-how, which needs to be pooled in a professional secretariat and panels composed of ad hoc or permanent arbitrators. Secondly, the findings will be subject to appeal. But other than the Appellate Body, in operation until 2020, the standard of review of legal findings in the revised system of WTO dispute settlement under the Dispute Settlement Understanding should in my view in principle be limited to a more deferential standard of reasonableness. Full review would be limited to systemic issues which essentially entail the interfacing of different traits of international economic law and of general public international law. The appeal stage, in other words, is essentially limited to what may be termed constitutional issues in linking the different traits of international economic law. As a consequence, it can be expected that the number of appeals will be limited and no longer reach $70 \%$ of all cases, as was the case before. There would no longer be an almost mandatory de facto twotier system.

The panel and appeal mechanism of the WTO applies to the agreements under the WTO, as amended to include competition and investment law or any other existing and new fields. It could, however, also be empowered by making it available for the assessment of treaty obligations outside of the WTO. This is the idea of a general court in international economic law, properly composed to reflect all the different traits of international economic law. Preferential trade agreements, which often make available dispute resolution framed upon the WTO panel system, face the problem of lacking institutional support and critical mass comparable to the multilateral system. Ad hoc arbitration risks problems of coherence and continuity, comparable to past experience in investment protection. International agreements, in particular bilateral and plurilateral trade and cooperation agreements, therefore could refer disputes to the central system of the WTO. The same holds true for existing investment protection agreements. They all could do so completely, or for the appeal stage only, reviewing the award of an arbitration tribunal. 
They could seek the option of advisory opinions by the appeal mechanism of the WTO. They could offer the option of preliminary rulings, and they could define the status of private parties, including the right to bring complaints and appeal rulings under the jurisdiction granted.

From this perspective, it is submitted that current efforts to bring about special appeal mechanisms in investment protection law, following the debate on the Comprehensive Economic and Trade Agreement (CETA), should be reassessed. Instead of creating a new body and court of law, the expertise and critical mass needed to review arbitration awards and BITs could instead be developed within the WTO appeal mechanism, granting private actors standing in this field. The same approach could be pursued for competition law, perhaps even assigning the determination of mergers of global companies to the global level. Nations are free to choose and shape their courts of law and can agree on treaty law or ad hoc by consent. The model sketched here does not conflict with BIT s (if amended), the standard function of WTO dispute settlement, the jurisdiction of the International Court of Justice or other standing bodies, such as the Permanent Court of Arbitration or ad hoc tribunals under international law. Rather, it creates additional options for States and international organizations to consider. It should be further explored in the process of reforming WTO dispute settlement.

International economic law will continue to grow incrementally, commensurate with transnational regulatory needs. It cannot develop the aspiration of a top down, comprehensive and fully consistent legal order. But international economic lawyers and academia should leave epistemic fragmentation behind and prepare the ground for greater coherence within an intellectual, shared constitutional framework and common understanding, both in terms of substantive and procedural law. The inclusion of competition and investment law and the reform of dispute settlement in the WTO, linking it up with existing agreements, offers the first steps on a long journey. It may, in due course, even entail issues of harmonized corporate tax law, induced by technological change and evolution.

\section{Biographical Note}

Emeritus Professor of European and International Economic Law, Senior Research Fellow, World Trade Institute, University of Bern and adjunct Professor of Law, University of Ottawa. 